\section{A Tame Platypus}

RECENTty an observant and interested resident at Healesville, which is about forty miles from Melbourne, prepared an artificial rectangular trough filled with water and mud to which was attached a straw-lined tube above the water level. He then placed a platypus in this structure and fed him regularly on the only diet available in quantity, namely, earthworms. Mollusca and shrimps were not procurable, at all events in quantity. Within three months this excessively shy creature emerged when whistled for and took worms furnished by hand. The diet required was from twelve to fourteen ounces daily for an animal which weighs less than three pounds.

This platypus is quite indifferent to the presence of a large number of visitors, and after being satiated with food climbs upon a ledge and cleans its beautiful fur with the movable claws projecting from the webbed hind feet. The practical problem is the supply of food in sufficient quantity. An effort is being made to face this difficulty by the establishment of a wormbreeding area.

Those of us who know how shy the platypus is in the wild state were amazed at the result on June 9 of 110 days of semi-captivity. The animals have, of course, been kept before in captivity, but never, I fancy, has domestication been practised with so much method and trouble.

It may be that the relatively large amount of food taken is due to the possibility that the worms alone do not provide a balanced diet. Similar experiments when other food is available in quantity may throw light on that problem.

Much information is contained in Burrell's classical work on the platypus. This particular incident has, however, aroused much interest and is full of possible information with regard to an extraordinary animal which, I am thankful to say, is holding its own and is apparently, with the legal protection it receives, in no danger of extinction.

At the date of writing the platypus is still alive. It is now mid-winter and the animal shows a tendency to sleep for two or three days at a time. It has now been in captivity 153 days.

\section{Collins Street, \\ Melbourne, C.1.} July 22.

\section{Nature and Science in Poetry}

It is not difficult to imagine how Herculean must have been the effort of the writer of the article in NATURE of August 26 under the above heading, to curb his pen. One realises the strength of mind required to put firmly on one side "La Semaine" of Guillaume de Saluste, Sieur du Bartas (1578); the "De Laudibus Dei" of Blossius Emilius Dracontius (Fifth Century); and the many references in Dr. Charles Singer's works on oriental science.

There must have occurred to the minds of many readers of NATURE the quatrain of Omar Khayyám :

Those who have become Oceans of Excellence and Cultivation,

And from the Collection of their Perfections have become the Lights of their Fellows,

Have not made a Road out of this Dark Night,

They have told a Fable, and have gone to Sleep, magnificently rendered by FitzGerald :

The Revelations of Devout and Learn'd Who rose before us and as Prophets burn'd,

Are all but Stories, which, awoke from Sleep,

They told their Comrades, and to Sleep returned.

The couplet of Alfred Austin reminded me of an amazing poem by a too-little known author-Mr. John Litart-entitled "Death and Disease"-which opens with the lines:

Oh! happy, happy death, release from earthly cares,

Think of the thousands who suffer through years and years,

In such suffering and pain of a hundred kinds, And the misery that is borne by all mankind,

Some which even the skill of the surgeon can't bind, Disease of the body, and disease of the mind.

A single verse will give an idea of this masterpiece :

There is rheumatic gout and many will say They are scarce free from suffering an hour a day. Then there is cancer a most terrible disease,

The pain and tortures it gives will make one's blood freeze.

Great suffering, a living death, a gnawing pain,

The surgeon's art no good, aleviation (sic) vain.

There are fifty lines, all up to this standard!

This may, I think, be claimed as marking the nadir of scientific 'versification': to my mind the zenith was attained by the exquisite and delicate fantasy of the late Sir Arthur Shipley in his little poem :

When we were a soft Amœba

In ages past and gone,

Ere you were Queen of Sheba, And I, King Solomon,

Alone and undivided

We lived a life of sloth,

Whatever you did, I did,

One dinner did for both.

At length came separation

By fission and divorce,

A lonely pseudopodium

I wandered on my course.

Edward Heron-Alt.en.

Influence of Certain Agents on the Lability of the 'Reducing Factor' (Vitamin C?) in Milk

IN a recent letter to NATURE ${ }^{1}$ attention was directed to the marked fluctuations which were observed in the concentration of the substance or substances in milk responsible for the reduction of $2: 6$ dichlorophenol-indophenol when the test of Birch, Harris and Ray ${ }^{2}$ for the chemical estimation of vitamin $\mathrm{C}$ was applied. It was pointed out that, even under the best conditions of production and distribution, the presence of a reasonable concentration of the reducing substances in milk cannot be guaranteed. Since that date, other experiments have been carried out to determine the reason for the fluctuations observed and two correlations which we believe to be significant have been found.

Identical samples of milk in sale glass bottles, one exposed to the light (none of the samples was at any time in direct sunlight since they were kept under a roof), another completely covered with 